\title{
EMPATI MAHASISWA ETNIS BETAWI PROGRAM STUDI BIMBINGAN DAN KONSELING PADA UNIVERSITAS NEGERI JAKARTA
}

\author{
Chandra Jon Trafolta ${ }^{1}$ \\ Moch. Dimyati, M.Pd ${ }^{2}$ \\ Dr. Awaluddin Tjalla ${ }^{3}$
}

\begin{abstract}
Abstrak
Penelitian ini bertujuan untuk memperoleh gambaran empati mahasiswa etnis Betawi program studi Bimbingan dan Konseling pada beberapa Universitas di DKI Jakarta. Metode yang digunakan adalah deskriptif dengan jenis penelitian survey. Populasi dalam penelitian ini berjumlah 30 mahasiswa etnis Betawi program studi Bimbingan dan Konseling dari 4 Universitas di DKI Jakarta; Universitas Negeri Jakarta (UNJ), Universitas Katolik Atma Jaya, Universitas Muhammadiyah Prof. DR. Hamka (UHAMKA), dan Universitas Islam Assafi' 'iyah. Instrumen yang digunakan adalah instrumen Empati dari Darrick Jollife dan David P Farrington (2006) dengan $r=0,857$. Pengujian instrumen diolah dengan menggunakan SPSS 17.0.Uji Validitas dari 20 butir pernyataan terdapat 17 butir pernyataan yang valid dan 3 butir pernyataan yang tidak valid.Butir-butir pernyataan yang tidak valid di revisi dan diperbaiki redaksinya menjadi pernyataan baru. Hasil penelitian empati mahasiswa etnis Betawi program studi Bimbingan dan Konseling berada pada kategori tinggi sebesar 73\%, pada kategori sedang diperoleh sebanyak 27\%, sedangkan pada kategori rendah diperoleh $0 \%$. Berdasarkan hasil yang didapatkan, bahwa sebagian besar empati mahasiswa etnis Betawi Bimbingan dan Konseling berada pada kategori tinggi.Implikasi dalam penelitian ini adalah untuk mahasiswa yang berada pada ketegori sedang, untuk lebih meningkatkan empatinya, yaitu dengan memanfaatkan media seperti televisi, ataupun film yang mengandung unsur-unsur empati.Dengan melihat langsung melaui film dapat menumbuhkan secara lansung perasaan empati kita pada film tersebut, dan bagaimana kita merespon atau memandangnya.
\end{abstract}

Kata Kunci : Empati, Mahasiswa Program Studi Bimbingan dan Konseling

\section{Pendahuluan}

Pendidikan merupakan bagian penting dalam pembangunan sebuah bangsa, bertujuan untuk mengembangkan Sumber Daya Manusia (SDM) yang berkualitas, dan menghasilkan manusia dengan memiliki nilai-nilai moral yang diakui ma- syarakat Indonesia.Pendidikan karakter merupakan usaha yang dilakukan oleh para personil sekolah, bahkan yang dilakukan bersama-sama dengan orang tua, dan anggota masyarakat, untuk membantu anak-anak dan remaja agar menjadi atau memiliki sifat peduli, berpendirian, dan bertanggung jawab

\footnotetext{
1 Mahasiswa Jurusan Bimbingan dan Konseling FIP UNJ, chandranababan92@gmail.com

2 Dosen Bimbingan dan Konseling FIP UNJ, moch_dimyati@yahoo.com

3 Dosen Bimbingan dan Konseling FIP UNJ, awaluddintjalla@yahoo.com
} 
(Williams, 1999).Dengan penjelasan tersebut, peran konselor sangat penting untuk membimbing, dan membentuk karakter pribadi bagi peserta didik.Konselor berperan dan berfungsi sebagai seorang pendidik, dengan perangkat pengetahuan dan keterampilan psikologis yang dimilikinya untuk membantu individu mencapai tingkat perkembangan yang lebih tinggi (Prayitno, 2004). Peran yang harus ada pada diri konselor yang ideal ataupun profesional hendaknya, memiliki kompetensi kepribadian seperti empati. Empati merupakan salah satu karakteristik kepribadian konselor yang penting, dan berpengaruh juga pada efektif atau tidaknya hubungan, dan proses konseling (Latipun, 2003).

Selain itu, empati merupakan kemampuan seseorang untuk mengerti tentang perasaan dan emosi orang lain serta kemampuan untuk membayangkan diri sendiri di tempat orang lain (Hurlock, 1999). Kemudian empati terbagi menjadi dua aspek, yaitu: aspek kognitif, dan aspek afektif. Aspek kognitif merupakan pemahaman seseorang pada emosi orang lain, sedangkan aspek afektif sebagai keselarasan efektif seseorang pada keadaan emosi orang lain(Darrick Jolliffe \& David P Farrington, 2006). Dengan itu kompetensi empati yang dimiliki konselor, hendaknya dipergunakan pada kehidupan bermasyarakat yang multicultural di DKI Jakarta, salah satunya pada konselor yang berasal dari etnis betawi. Etnis Betawi merupakan salah satu etnis yang memiliki keunikan tersendiri.Etnis Betawi merupakan campuran dari berbagai macam suku bangsa, baik dari suku bangsa yang ada di Indonesia maupun dari luar Indonesia (Cina, Eropa, dan Arab) yang kemudian menjadi suku bangsa Betawi (Magdalia Alfian, 2013).Kemudian etnis Betawi merupakan etnis yang berdomisili di Jakarta, dan sekitarnya yang menjadi penduduk asli Jakarta.Betawi juga merupakan etnis terlama yang ada di Indonesia (Ridwan Saidi, 2001).

Selanjutnya terdapat empati pada aspek kognitif yang tercerminkan dari etnis Betawi, yaitu mereka memahami perasaan orang lain untuk tidak menyakiti hatinya, dan menjaga keharmonisan bertentangga di lingkungannya (Alamsyah, 2004). Kemudian terdapat aspek afektif yang ditampilkan dari etnis Betawi ketika terjadinya musibah kematian pada orang lain, keluarga yang ditinggalkan tentu memerlukan dukungan moril dari warga masyarakat di sekitarnya. Dukungan tersebut bisa diwujudkan dengan cara melayat, sehingga dapat meringankan beban yang sedang dihadapi keluarga yang bersangkutan (Alamsyah, 2004).

Berdasarkan hal-hal tersebut, maka rumusan masalah dalam penelitian ini adalah "Bagaimanakah empati mahasiswa etnis Betawi program studi Bimbingan dan Konseling pada Universitas di DKI Jakarta?"

\section{Kajian Teori \\ Pengertian Empati}

Empati berkembang dalam diri seseorang secara alamiah sejak bayi dan masa-masa selanjutnya.Empati dapat diasah dan ditingkatkan dalam diri individu salah satunya melalui lingkungan disekitarnya. Akar empati sudah ada pada seseorang sejak mereka masih bayi atau sejak mereka lahir (Goleman, 1997).Kemampuan berempati sudah mulai muncul pada masa kanak-kanak awal (Hurlock, 1999).Karakter empati sudah dimulai sejak dini, namun karakter tersebut perlu dikembangakan ketika individu mulai berinteraksi dilingkungannya.Empati merupakan kemampuan seseorang untuk mengerti tentang perasaan dan emosi orang lain serta kemampuan untuk membayangkan diri sendiri di tempat orang lain (Hurlock, 1999).

Empati sebagai merupakan keterampilan komunikasi interpersonal, karena konselor berusaha untuk memahami konseli, dan mengkomunikasikan pemahamannya dengan tujuan membantu konseli agar lebih memahami dirinya sendiri (Egan 2008). Karakter empati merupakan bagian terpenting yang harus dimiliki konselor, karena untuk menempatkan perasaan konselor pada diri konseli yang mempu-nyai masalah, sehingga terjalin proses konseling yang diharapkan oleh konseli.

Kemudian di dalam Empati dikategorisasikan menjadi dua bagian, yaitu aspek kognitif adalah memahami perasaan keadaan emosi atau konteks seseorang, sedangkan aspek afektif adalahMenempatkan posisi diri pada keadaan emosi atau konteks seseorang (Darrick Jolliffe \& David P Farrington 2006). 


\section{Pengertian Etnis Betawi}

Etnis Betawi dianggap orang sekarang sebagai penduduk asli kota Jakarta. Asal usul mereka tidak dapat dipisahkan dari sejarah pertumbuhan kota Jakarta (Departemen Pendidikan dan Kebudayaan, 1988). Artinya, etnis Betawi merupakan etnis yang sudah melekat pada Jakarta atau bagian terpenting dari pertumbuhan kota Jakarta. Karakterisik etnis Betawi, menggunakan bahasa Indonesia namun dialek Betawi, lalu karakter bahasa lugas, humoris, ramah dan terbuka. Kemudian etnis Betawi sangat menjunjung tinggi nilai-nilai yang diajarkan kepadanya, seperti saling tolong menolong dan bergotong-royong. Adapun nilai-nilai yang dijadikan pedoman hidup antara lain, kedisplinan, gotong-royong, berbicara atau mendengarkan, dan sikap toleransi.

\section{Karaktersitik Mahasiswa}

Mahasiswa merupakan suatu kelompok dalam masyarakat yang memperoleh statusnya karena ikatan dengan perguruan tinggi (Anggia Putri, 2012). Karaktersitik dalam peneneltian ini adalah mahasiswa prodi Bimbingan dan Konseling, berusia 1824 tahun, dan mahasiswa etnis Betawi.

\section{Metodologi Penelitian}

Penelitian ini dilakukan di 4 Universitas di DKI Jakarta, Universitas Negeri Jakarta, UHAMKA, Katolik Atmajaya, UKI, dan Islam As-Syafi'iyah. Waktu penelitian dilakukan dari bulan Februari-Desember 2014.Penelitian ini menggunakan pendekatan kuantitatif deskriptif, jenis dalam penelitian ini adalah survei. Tujuan dari survei adalah untuk menggambarkan secara sistematis fakta, dan menginterpretasi objek dengan apa adanya (Sukardi, 2003).

Populasi pada penelitian ini yaitu mahasiswa etnis Betawi prodi Bimbingan dan Konseling, angka$\tan$ 2010-2013.Jumlah keseluruhan yang didapatkan sebanyak 30 mahasiswa etnis Betawi.Teknik pengambilan sampel yang dilakukan adalah teknik sampling jenuh.Teknik tersebut merupakan teknik yang digunakan peneliti untuk mengambil semua anggota populasi sebagai sampel, dengan harapan untuk memperkecil terjadinya kesalahan (Sugiyono 2010).Instrumen yang digunakan yaitu Basic Empahty Scale (BES) atau instrumen Skala Dasar Em- pati yang dikembangkan oleh Jollife \& Farrington.

Untuk uji coba instrumen dalam penelitian ini digunakan pengujian validitas dan reliabilitas menggunakan aplikasi SPSS versi 17.Pengujian validitas hasil uji coba instrumen Basic Empahty Scale (BES)terdapat 3 butir instrumen yang tidak valid atau drop dari jumlah keseluruhan 20 butir instrumen, dengan hasil reliabilitas sebesar 0.803 .

Pengambilan data menggunakan instrumen $\mathrm{Ba}-$ sic Empahty Scale (BES).Skala yang digunakan peneliti untuk mengukur variable yaitu model skala likert.model skala likert memberikan gambaran empati etnis Betawi melalui frekuensi sifat-sifat yang ditampilkan.

\section{Hasil dan Pembahasan Data Kesluruhan Etnis Betawi}

Tabel 4.1

Data Keseluruhan

\begin{tabular}{|c|c|c|c|}
\hline $\begin{array}{c}\text { Nilai } \\
\text { Kategorisasi }\end{array}$ & Kategorisasi & $\begin{array}{c}\text { Jumlah } \\
\text { Orang }\end{array}$ & Presentase \\
\hline$\geq 73$ & Tinggi & 22 & $73 \%$ \\
\hline $47-72$ & Sedang & 8 & $27 \%$ \\
\hline$<47$ & Rendah & 0 & $0 \%$ \\
\hline \multicolumn{2}{|c|}{ Total } & 30 & $100 \%$ \\
\hline
\end{tabular}

Untuk lebih jelasanya, perbedaan tinggi, sedang, rendahnya persentase dari masing-masing kategori dapat dilihat pada grafik 4.2 berikut:

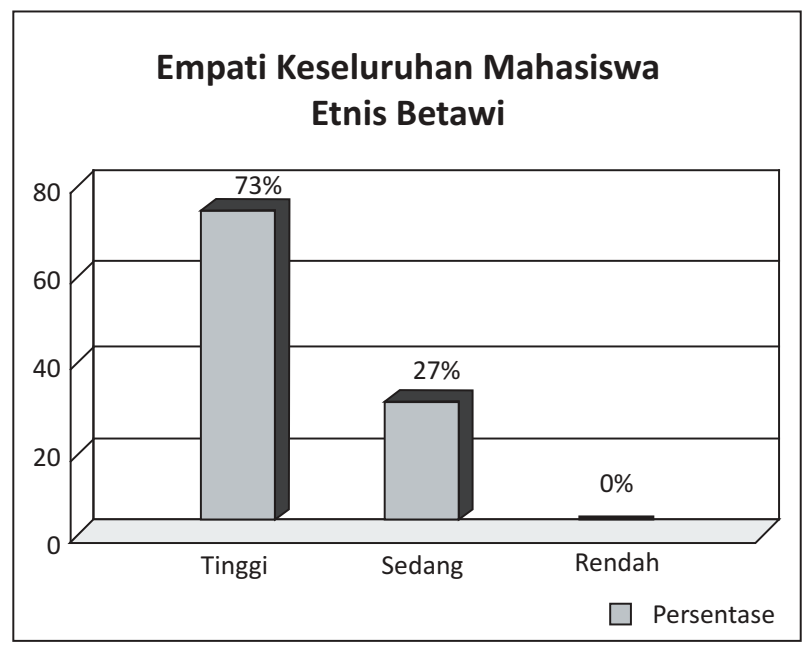

Grafik 4.2. Data Secara Keseluruhan

Berdasarkan data keseluruhan pada tabel 4.1 dan grafik 4.2 di atas, diperoleh hasil persentase kese- 
luruhan empati mahasiswa etnis Betawi prodi Bimbingan dan Konseling di DKI Jakarta.Empati yang tinggi terdapat persentase paling dominan sebesar $73 \%$. Kemudian pada empati sedang diperoleh dengan persentase sebanyak $27 \%$.Sedangkan pada empati rendah diperoleh nihil dengan persentase $0 \%$.Berdasarkan uraian empati keseluruhan mahasiswa etnis Betawi, secara keseluruhan berada pada empati yang tinggi.

\section{Data Aspek Afektif}

Tabel 4.3

Data Keseluruhan Aspek Afektif

\begin{tabular}{|c|c|c|c|}
\hline $\begin{array}{c}\text { Nilai } \\
\text { Kategorisasi }\end{array}$ & Kategorisasi & $\begin{array}{c}\text { Jumlah } \\
\text { Orang }\end{array}$ & Presentase \\
\hline$\geq \mathbf{4 0}$ & Tinggi & 20 & $67 \%$ \\
\hline $\mathbf{2 6 - 3 9}$ & Sedang & 10 & $33 \%$ \\
\hline$<\mathbf{2 6}$ & Rendah & 0 & $0 \%$ \\
\hline \multicolumn{2}{|c|}{ Total } & 30 & $100 \%$ \\
\hline
\end{tabular}

Untuk lebih jelas dapat dilihat grafik berikut:

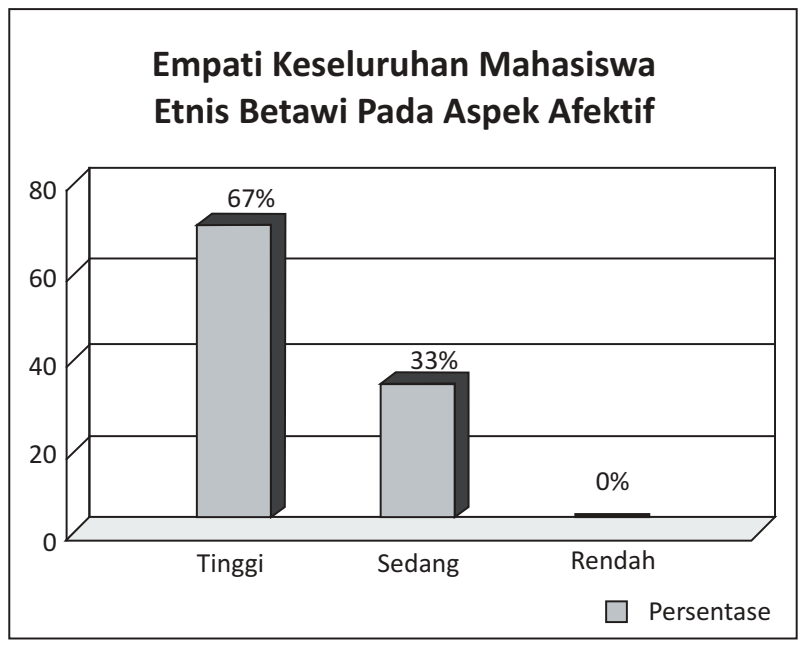

Grafik 4.4. Data Keselurahan Aspek Afektif

Berdasarkan data keseluruhan pada tabel 4.3 dan grafik 4.4, diperoleh hasil persentase empati mahasiswa etnis Betawi prodi Bimbingan dan Konseling di DKI Jakarta pada aspek afektif.Untuk aspek afektif tinggi terdapat persentase paling dominan sebesar $67 \%$.Kemudian pada kategori aspek afektifsedang diperoleh dengan persentase sebanyak 33\%. Sedangkan pada aspek afektif rendah diperoleh nihil dengan persentase $0 \%$.Berdasarkan uraian di atas menunjukan bahwa, empati mahasiswa etnis Betawi
Prodi Bimbingan dan Konseling di DKI Jakarta pada aspek afektif berada pada kategori tinggi.

\section{Aspek Kognitif}

Tabel 4.5

Data Keseluruhan Aspek Kognitif

\begin{tabular}{|c|c|c|c|}
\hline $\begin{array}{c}\text { Nilai } \\
\text { Kategorisasi }\end{array}$ & Kategorisasi & $\begin{array}{c}\text { Jumlah } \\
\text { Orang }\end{array}$ & Presentase \\
\hline$\geq \mathbf{3 3}$ & Tinggi & 28 & $93 \%$ \\
\hline $\mathbf{2 1 ~ - 3 2}$ & Sedang & 2 & $7 \%$ \\
\hline$<\mathbf{2 1}$ & Rendah & 0 & $0 \%$ \\
\hline \multicolumn{2}{|c|}{ Total } & 30 & $100 \%$ \\
\hline
\end{tabular}

Untuk lebih jelas dapat dilihat grafik berikut:

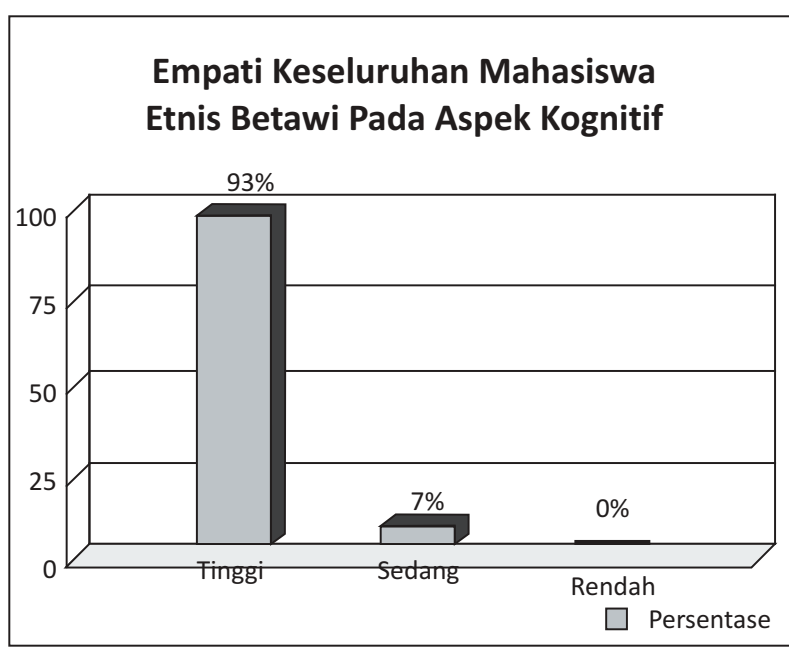

Grafik 4.6

Data Keselurahan Aspek Kognitif

Berdasarkan data keseluruhan pada tabel 4.5 dan grafik 4.6, diperoleh hasil persentase empati mahasiswa etnis Betawi prodi Bimbingan dan Konseling di DKI Jakarta pada aspek kognitif.Untuk aspek kognitif tinggi terdapat persentase paling dominan sebesar 93\%.Kemudian pada aspek kognitif sedang diperoleh dengan persentase sebanyak 7\%.Sedangkan pada aspek rendah diperoleh nihil dengan persentase $0 \%$.Hasil tersebut menunjukan bahwa, empati mahasiswa etnis Betawi Prodi Bimbingan dan Konseling di DKI Jakarta pada aspek kognitif berada pada kategori tinggi.

\section{Kesimpulan dan Saran}

Berdasarkan hasil penelitian dan analisis hasil penelitian mengenai empati mahasiswa etnis Betawi 
program studi Bimbingan dan Konseling di 4 Universitas di DKI Jakarta, diperoleh gambaran empati mahasiswa etnis Betawi secara keseluruhan aspek afektif, dan kognitif, berdasarkan per Universitas sebagai berikut:

1. Hasil penelitian secara keseluruhan, total skor empati mahsiswa Bimbingan dan Konseling dari empat Universitas di DKI Jalarta berjumlah 30 responden. Secara mayoritas berada pada kategori tinggi, diperoleh dengan persentase sebesar $73 \%$ dengan jumlah 22 mahasiswa. Untuk kategori sedang diperoleh persentase sebanyak $27 \%$ dengan jumlah 8 mahasiswa, sedangkan pada mahasiswa kategori rendah nihil dengan persentase $0 \%$.

2. Empati mahasiswa etnis Betawi pada aspek afektif yaitu berada pada kategori tinggi dengan persentase $67 \%$.

3. Empati mahsiswa etnis Betawi pada aspek kognitif yaitu berada pada kategori tinggi dengan persentase $28 \%$.

4. Empati mahasiswa etnis betawi prodi BK di UNJ diperoleh dengan jumlah paling dominan 11 $(100 \%)$ mahasiswa berada pada kategori tinggi, kemudian tidak didapatkan pada hasil kategori sedang, dan rendah.

5. Empati mahasiswa etnis betawi prodi BK di Universitas Katolik Atma Jaya diperoleh dengan jumlah responden 1 mahasiswa dengan persentase $14 \%$ berada pada kategori sedang.

6. Empati mahasiswa etnis betawi prodi BK di UHAMKA diperoleh dengan jumlah paling dominan 7 (64\%) mahasiswa berada pada kategori sedang, kemudian dengan jumlah 4 mahasiswa dengan persentase $36 \%$ berada pada kategori tinggi, dan tidak didapatkan hasil dari kategori rendah pada mahasiswa.

7. Empati mahasiswa etnis betawi prodi BK di Universitas Islam Assafi' iyah diperoleh dengan jumlah paling dominan $6(86 \%)$ mahasiswa berada pada kategori tinggi, kemudian dengan jumlah 1 (14\%) mahasiswa berada pada kategori sedang, dan selanjutnya untuk hasil kategori rendah tidak didapatkan dari mahasiswa.

\section{Saran}

Saran-saran yang dapat menjadi pertimbangan berdasarkan hasil penelitian ini adalah:

\section{Bagi Calon Konselor}

Bagi calon konselor agar dapat lebih meningkatkan empati dengan melihat langsung melalui media seperti televisi, ataupun video yang terkait dengan informasi empati, akan dapat menumbuhkan dan mengembangkan perasaan empati.

\section{Bagi Jurusan Bimbingan dan Konseling}

Untuk jurusan Bimbingan dan Konseling dengan mengembangkan sendiri media belajar terkait dengan empati, dan mengembangkan program kepelatihan, dan bekerja sama dengan berbgai pihak tentang meningkatkan empati dengan mahasiswa.

\section{Bagi peniliti selanjutnya}

Bagi mahasiswa yang akan mengembangkan penelitian ini, disarankan untuk mencari referensi yang lebih luas, untuk mengambangkan sumber, fokus yang terkait tentang empati, seperti melakukan penelitian eksperimen dengan teknik role playing, dan kemudian memberikan pelatihan kepada mereka yang memiliki empati sedang, maupun empati yang rendah.

\section{Daftar Pustaka}

Alamsyah, Muwardi dkk.(2004). Fungsi Keluarga dalam Pemahaman Nilai-Nilai Budaya Pada Masyarakat Betawi di DKI Jakarta. Laporan Hasil Penelitian. Jakarta: Kementrian Pendidikan dan kebudayaan.

Alfian.(2013). Potensi Kearifan Lokal dalam Pembentukan Jari Diri dan Karakter Bangsa.Skripsi (tidak diterbitkan), Jakarta: Fakultas Ilmu Pengetahuan BudayaUniversitas Indonesia.

Goleman, Daniel. (1997). Emotional Intelligence. Jakarta: PT Gramedia Pustaka Utama.

Hurlock, Elizabeth. (1999). Perkembangan anak. Jilid 2. Alih Bahasa: Med. Meitasari Tjandrasa dkk. (Edisi keenam). Jakarta: Penerbit Erlangga.

Jollife, Darrick \& Farrington, David P. (2006).Develop- 
ment and Validation Basic Empathy Scale. Laporan Penelitian. England: Institute of Criminology-University of Cambridge.

Latipun. (2003). Psikologi Konseling, Malang: UMM Press.

Prayitno \& Amti, E. (2004). Dasar-Dasar Bimbingan dan Konseling. Jakarta: Rineka Cipta.

Saidi, Ridwan. (1994). Orang Betawi dan Modernisasi. Jakarta: LSIP. Cet. Ke-1.

Saidi, Ridwan. (2001). Profil Orang Betawi, Asal Mua- sal, Kebudayaan, dan Adat Istiadatnya, Jakarta: PT. Gunara Kata.

Sugiyono. (2010). Metode Penelitian Pendidikan, Bandung: Alfabeta.

Sukardi.(2003). Metodologi Penelitian Pendidikan. Jakarta: PT Bumi Askara.

Williams dkk. (1999). Character Education: The foundation for teacher education, DC: Character Education Partnership. 